\title{
Assessment of quality of life in patients with cerebral palsy
}

\author{
Marta Lewicka' ${ }^{1}$ Andrzej Kurylak² \\ 'Department of Social Nursing, Faculty of Health Sciences, Ludwik Rydygier Collegium Medicum in Bydgoszcz, \\ Nicolaus Copernicus University in Torun, Poland \\ 2Department of Paediatric Nursing, Faculty of Health Sciences, Ludwik Rydygier Collegium Medicum in Bydgoszcz, \\ Nicolaus Copernicus University in Torun, Poland
}

\section{ABSTRACT}

Introduction: The quality of life improvement in children with cerebral palsy has become one of the main goals of therapeutic intervention, in parallel with the relief of disease symptoms. Unfortunately, the number of Polish publications on the quality of life of this group is relatively small compared to other countries.

Aim of the study: The aim of this paper was the assessment of the quality of life of children with cerebral palsy. Material and methods: The study group included 128 persons with cerebral palsy aged two to 18 years. The study was of prospective nature and was carried out using the diagnostic survey method with the use of two standardised tools: PedsQL 3.0 Cerebral Palsy Module and CP QOL-Child Questionnaire. All calculations and figures were made using Microsoft Excel and Statistica 10.0 software.

Results: The least frequently reported problems on the PedsQL 3.0 scale were pain (68.02 points) and fatigue (58.40 points). The most difficult for cerebral palsy patients were everyday activities (32.31 points), and mobility and keeping balance (39.41 points). The lowest scores of all domains in the CP QOL-Child questionnaire were received by the access to health services -56.24 points, and physical health and participation 58.99 points. According to the surveyed patients, their highest quality of life occurs in the area of participation in social life and social acceptance - 75.71 points, and emotional state -75.27 points

Conclusions: The results show a deficit in the quality of life of children and youths with cerebral palsy in terms of physical, social, and school life as well as in terms of problems arising from the disease entity. The therapy should be focused on appropriate adjustment of the home and school environment to the patient's needs, as well as developing skills that enable self-care or assisting in everyday self-care and school activities.

\section{KEY WORDS:}

children, quality of life, cerebral palsy.

\section{INTRODUCTION}

Cerebral palsy (paralysis cerbralis infantium - CP) is a disease entity of complex consequences affecting biological, physical, and social functioning $[1,2]$. The inconsistency of disease symptoms affects the organisation of the life of a child and his/her family [3,4]. Achievement of the highest level of independence as regards motor, emotional, or social functions is possible upon applying a multi-directional assessment in order to program comprehensive therapy performed by a group of specialists. The efficiency of therapy is measured by regular clinical and functional assessment. The quality of life assessment applied simultaneously to the aforementioned assessments is equally important [4].

\section{ADDRESS FOR CORRESPONDENCE:}

Marta Lewicka, Department of Social Nursing, Faculty of Health Sciences, Ludwik Rydygier Collegium

Medicum in Bydgoszcz, Nicolaus Copernicus University in Torun, 1 Łukasiewicza St., 85-001 Bydgoszcz,

Poland, ORCID: 0000-0002-6190-1895, e-mail: marta_grabinska@hotmail.com 
The measurement of the patients' quality of life reflects a holistic approach to patients with cerebral palsy, who are the recipients of care. Its objective is special when considered in the context of the care efficiency indicator. The improvement in the quality of life of patients suffering from chronic non-infectious diseases, to which cerebral palsy undoubtedly belongs, is one of the priorities of the European Union and is encompassed in the European Commission's program "European Disability for 2010-2020: A Renewed Commitment to a Barrier-Free Europe" [5]. Bearing in mind that cerebral palsy is the most common cause of motor disability among children $[2,6]$ and considering the small number of reports on the quality of life of patients with cerebral palsy in Polish literature, a study has been undertaken aimed at learning the general quality of life of children and adolescents with cerebral palsy.

\section{MATERIAL AND METHODS}

A total of 150 patients aged two to 18 years and their parents were qualified for the study. During data acquisition, nine parents/guardians did not agree to participate in the study, and 14 returned incomplete questionnaires. The final group of patients who participated in the study covered 128 persons, including 61 boys and 67 girls. Most of the respondents indicated that the child had confirmed tetraplegia - 57 people $(44.5 \%)$ or hemiplegia - 46 people (35.9\%). The least indicated was congenital ataxia - three people $(2.3 \%)$ or an athletic person - one person $(0.8 \%)$. Nobody pointed to the mixed character.

The questionnaires used in the study were not filled out by patients with cerebral palsy themselves but by their parents. The self-assessment of patients was abandoned due to mental disability and communication difficulties with the majority of them.

The research was carried among patients under the care of the Josef Brudziński Provincial Children's Hospital in Bydgoszcz. The study was of prospective nature and was carried out using the diagnostic survey method with the use of two standardised tools: PedsQL 3.0 Cerebal Palsy Module and CP QOL-Child.

PedsQL 3.0 Cerebral Palsy Module includes a 35-point evaluation of seven spheres: everyday activities, and those performed at school, mobility and keeping balance, pain, fatigue, activities related to eating, as well as speech and communication. The responses are converted according to the five-point Likert scale, obtaining numerical values from 0 to 100, where a score of 100 means the best quality of life. Questions are modified according to the age of the children surveyed and there are versions for a child and a parent/guardian (for children aged 2-4 years, school functioning and communication are not assessed).

CP QOL-Child was designed so as to assess the quality of life in terms of well-being instead of the disease. It examines seven domains of the patient's life: participation in social life and social acceptance, functioning, physical health and participation, emotional condition, pain and disability effects, access to health services, and health of parents and guardians. The questionnaire contains questions pertaining to the child's feelings as regards a given domain, and the answers are marked on a nine-point scale: from one to nine, where one means very dissatisfied and nine very satisfied.

The pre-condition for inclusion in the study group was diagnosed cerebral palsy; child age of 2-18 years; consent of the child's parent/guardian to undergo the survey; fulfilment of the declaration of consent to participate in the study; and filling out the questionnaire while being familiar with the study's purpose and method.

The preconditions for excluding a child from the study group were: no diagnosed cerebral palsy; age less than two years; other chronic disease not resulting from the underlying disease entity; no consent of the child's parent/guardian to undergo the survey; failure to complete the declaration of consent to participate in the study; and failure to fill out the questionnaire about being familiar with the purpose and the method of the study.

The study has been carried out on the basis of the consent (No. KB/469/2014) of the Bioethics Committee of Nicholas Copernicus University in Torun at the Ludwik Rydygier Collegium Medicum in Bydgoszcz.

The Kruskal-Wallis rank test was used in the statistical study. All calculations and figures were made using a Microsoft Excel spreadsheet, which is part of the Microsoft Office suit, and using Statistica 10.0 software.

\section{RESULTS}

\section{ANALYSIS OF THE PEDSQL 3.0 QUESTIONNAIRE}

The least frequently reported problems on the PedsQL 3.0 Cerebral Palsy Module specific scale were pain (68.02 points) and fatigue (58.40 points). Everyday activities (32.31 points), as well as mobility and keeping balance (39.41 points), were the most difficult for cerebral palsy patients, followed by school activities (40.99 points), eating (49.18 points), and speech and communication (49.87 points). Figure 1 shows the mean values of the PedsQL 3.0 questionnaire scale items.

The analysis shows a relationship between the type of cerebral palsy and the quality of life. The lowest results in all items were obtained by patients with tetraplegia (Fig. 2). Due to the level of significance $(p<0.05)$ there were statistically significant differences between the examined groups of cerebral palsy type, concerning all items of the PedsQL 3.0 questionnaire scale.

\section{ANALYSIS OF THE CPQOL CHILD QUESTIONNAIRE}

The lowest score of all domains was received by the access to health services (56.24 points) and physical 


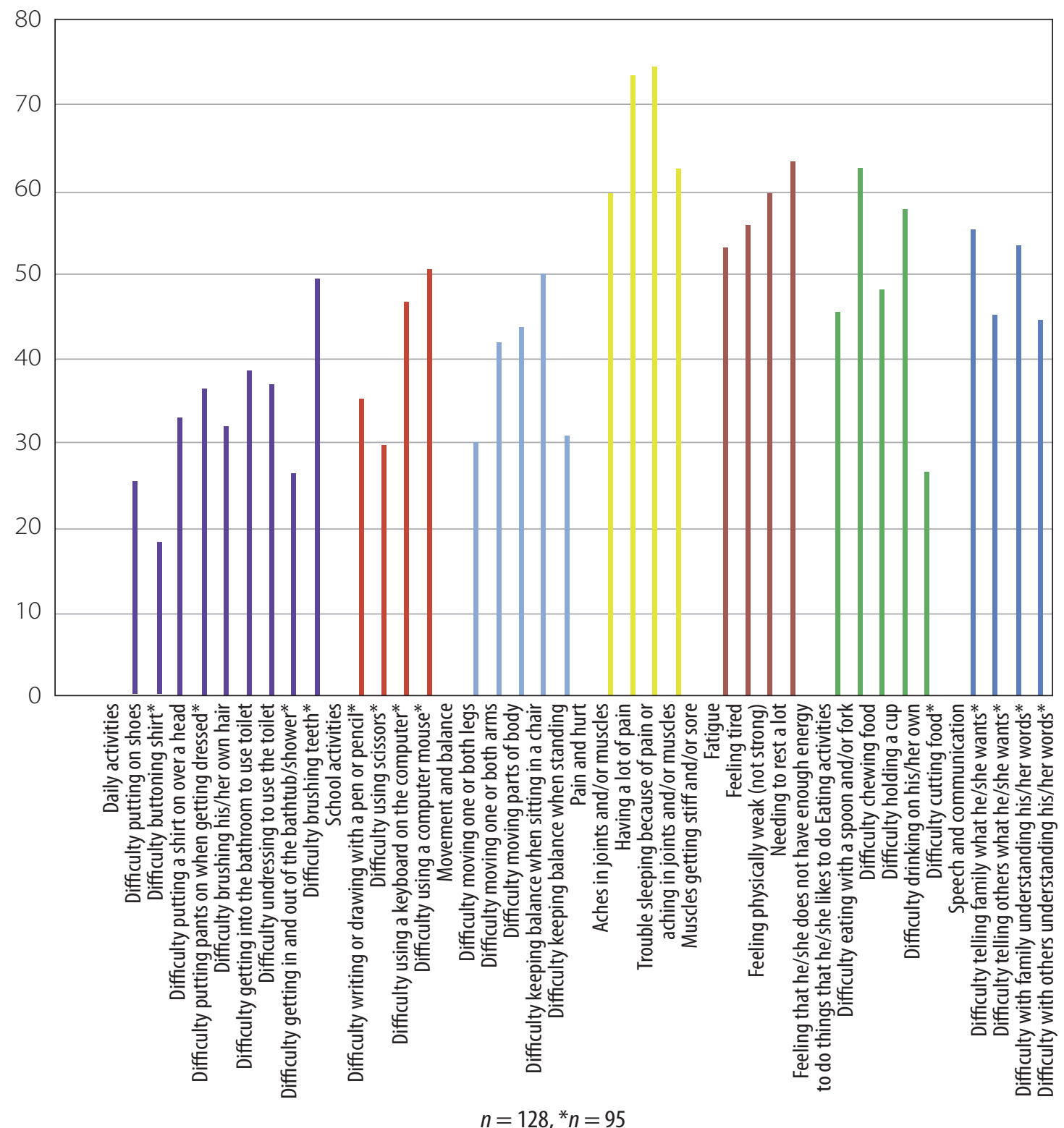

FIGURE 1. The average position of the PedsQL 3.0 questionnaire scale

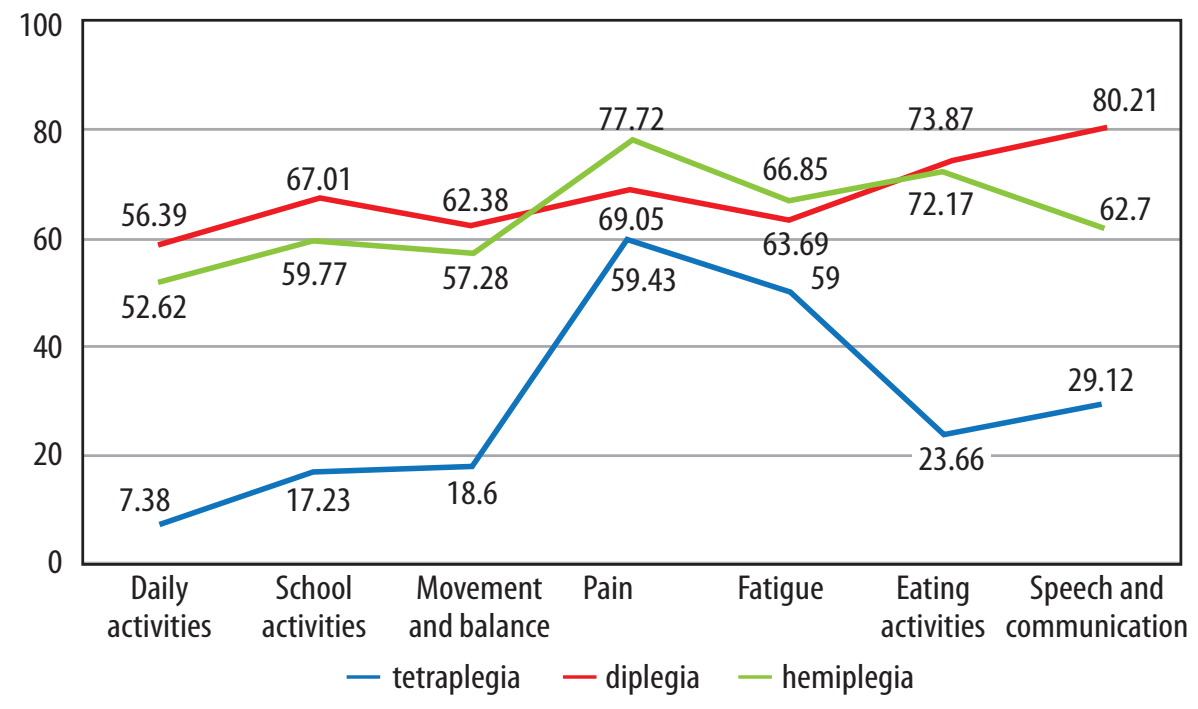

FIGURE 2. Distribution of average functioning scales of PedsQL 3.0 in groups of cerebral palsy 
health and participation (58.99 points). According to the surveyed patients, their highest quality of life occurred in the area of participation in social life, social acceptance (75.71 points) and emotional state (75.27 points) followed by pain and disability effects (63.86 points), functioning (62.35 points), and the health of parents (60.54 points).

The average scores of individual items of the CP QOL Child questionnaire domains are shown in Table 1.

Material analysis shows a relationship between the type of cerebral palsy and the quality of life. Due to the level of significance $(p<0.05)$ there were statistically significant differences between the groups of cerebral palsy types tested, concerning the results of all areas, except for the pain and impact of disability and family health. The highest results in all areas except for family health were recorded in the group of children with diplegia. The best quality of life in family health were in the group of patients with hemiplegia. The lowest results in all areas were recorded in the group of children with tetraplegia. Detailed data are presented in Figure 3.

\section{DISCUSSION}

\section{QUALITY OF LIFE IN PATIENTS WITH CEREBRAL PALSY}

It should be noted that, in comparison with other countries, Polish professional literature provides few reports on the quality of life of children with cerebral palsy. Until 2014, studies on the quality of life in this group of patients were conducted in Poland only with the use of generic questionnaires or such generic questionnaires in which a module for the disease entity which is cerebral palsy was developed and which in this way gained the status of specific questionnaires [7]. Among the available papers, one should mention the study of Michalska et al. [8], where, as in the case of the author's own studies, Varnie's questionnaires were used. In turn, Okurowska-Zawada et al. used the KINDL-R questionnaire to determine the quality of life of children with cerebral palsy. Although that questionnaire assesses the quality of life dependent on the patient's health condition, it is also a generic questionnaire [9]. Chmielik et al. used CHQ-PF 50 (Child Health Questionnaire - Parent Form 50), the aim of which was to assess the general quality of life of healthy and chronically ill children, while the physical and psychosocial well-being domain is measured [10]. In 2014, Dmitruk published a paper on the quality of life of Polish children with cerebral palsy, in which she presented preliminary results concerning the process of CP QOL-Child questionnaire validation - a tool specific to children with cerebral palsy. Since 2014, it has been possible to thoroughly familiarise oneself with the quality of life of Polish children with cerebral palsy. This questionnaire was also used in the author's own studies [7].
The results of the author's own research using the PedsQL 3.0 Cerebral Palsy Module are in line with the results obtained by Michalska [4,8] and are similar to the results obtained by Varni [11] and Yang [12]. They confirm the low level of children and youth functioning as regards every day and school activities, mobility and keeping balance, as well as eating and speech. In the results obtained by Varni, the lowest-rated components of the CP Module were everyday activities and school activities, mobility and keeping balance, as well as speech [11]. In Chinese studies, these are everyday and school activities, speech, and fatigue [12]. Consequently, it seems that the therapeutic goals for patients with cerebral palsy require special consideration. Therapy should be focused on appropriate adjustment of the home and school environment to the patient's needs, as well as developing such skills that enable self-care or assisting in everyday self-care (personal hygiene, getting dressed) and school activities. It is also extremely important for non-speaking patients or patients with limited speaking abilities to use the Augmentative and Alternative Communication (AAC) methods, thanks to which they can overcome communication barriers [8].

The issue of pain, both in the author's own research and in American, Chinese, and Polish studies, was the least frequently reported problem assessed using the module for children with cerebral palsy $[8,11,12]$. However, the results presented by other researchers indicate that pain is often reported, in particular by people with severe motor deficits and in the presence of gastrostomy [13]. Hirsh et al. [14], Arnaud [15], and Michalska [4, 8] draw attention to the inadequate assessment of the intensity of pain. As they note, this may be the result of the patient's mental disability, problems with communication, or lack of parents' or guardians' knowledge $[13,14]$. It seems that the most appropriate action, and at the same time quite a challenge for medical staff working with children with cerebral palsy, is multidimensional education aimed at identifying symptoms, proper pain assessment, and making parents and guardians aware of its possible causes and symptoms.

Varni et al. concluded that children with tetraplegia experience a greater severity of pain than children with hemi- or diplegia. This conclusion has been confirmed both in studies conducted among the patients themselves and among their parents. The studies also showed a significant and inverse relationship between the severity of pain and school-related functioning [11]. In turn, Houlihan et al. discovered a significant and positive relationship between pain and the number of missed school days [13]. Berrin et al. also dealt with the problem of pain, paying attention to differences in assessment between children and parents. As compared with their parents, children reported less pain and fatigue, which corresponded to higher CP Module scores. In the same studies, it was also stressed that pain and fatigue are important factors 
TABLE 1. The average position of CP QOL-Child questionnaire

\begin{tabular}{|c|c|c|c|c|c|c|c|c|c|c|}
\hline Group & $n$ & Average & SD & $-\mathrm{Cl} 95 \%$ & $+\mathrm{Cl} 95 \%$ & Min & Max & Q25 & Median & Q75 \\
\hline \multicolumn{11}{|c|}{ Social well-being and acceptance } \\
\hline $\begin{array}{l}\text { The way they get along } \\
\text { with people generally }\end{array}$ & 70 & 74.64 & 18.303 & 70.28 & 79.01 & 25.00 & 100.00 & 62.50 & 75.00 & 87.50 \\
\hline $\begin{array}{l}\text { The way they get along } \\
\text { with their siblings }\end{array}$ & 49 & 79.34 & 20.018 & 73.59 & 85.09 & 25.00 & 100.00 & 75.00 & 75.00 & 100.00 \\
\hline $\begin{array}{l}\text { The way they get along } \\
\text { with other children at } \\
\text { preschool or school }\end{array}$ & 60 & 76.67 & 17.294 & 72.20 & 81.13 & 25.00 & 100.00 & 75.00 & 75.00 & 87.50 \\
\hline $\begin{array}{l}\text { The way they get along } \\
\text { with other children outside } \\
\text { preschool or school }\end{array}$ & 70 & 74.82 & 18.855 & 70.33 & 79.32 & 25.00 & 100.00 & 62.50 & 75.00 & 87.50 \\
\hline $\begin{array}{l}\text { The way they get along } \\
\text { with adults }\end{array}$ & 70 & 78.39 & 15.036 & 74.81 & 81.98 & 50.00 & 100.00 & 75.00 & 75.00 & 87.50 \\
\hline $\begin{array}{l}\text { The way they get along } \\
\text { with their teachers and/or } \\
\text { careers }\end{array}$ & 70 & 80.89 & 13.746 & 77.62 & 84.17 & 50.00 & 100.00 & 75.00 & 75.00 & 87.50 \\
\hline $\begin{array}{l}\text { Going out on trips with } \\
\text { families }\end{array}$ & 70 & 82.68 & 21.206 & 77.62 & 87.73 & 12.50 & 100.00 & 75.00 & 87.50 & 100.00 \\
\hline $\begin{array}{l}\text { How they are accepted by } \\
\text { their family }\end{array}$ & 70 & 83.04 & 19.740 & 78.33 & 87.74 & 25.00 & 100.00 & 75.00 & 87.50 & 100.00 \\
\hline $\begin{array}{l}\text { How they are accepted by } \\
\text { other children at preschool } \\
\text { or school }\end{array}$ & 59 & 72.88 & 19.988 & 67.67 & 78.09 & 25.00 & 100.00 & 50.00 & 75.00 & 87.50 \\
\hline $\begin{array}{l}\text { How they are accepted by } \\
\text { other children outside } \\
\text { of preschool or school }\end{array}$ & 70 & 65.36 & 22.134 & 60.08 & 70.63 & 25.00 & 100.00 & 50.00 & 62.50 & 87.50 \\
\hline $\begin{array}{l}\text { How they are accepted by } \\
\text { adults }\end{array}$ & 70 & 73.57 & 19.452 & 68.93 & 78.21 & 25.00 & 100.00 & 62.50 & 75.00 & 87.50 \\
\hline $\begin{array}{l}\text { How they are accepted by } \\
\text { people in general }\end{array}$ & 70 & 68.57 & 20.495 & 63.68 & 73.46 & 25.00 & 100.00 & 50.00 & 75.00 & 87.50 \\
\hline \multicolumn{11}{|l|}{ Feelings about functioning } \\
\hline $\begin{array}{l}\text { Their ability to play on their } \\
\text { own }\end{array}$ & 70 & 60.89 & 26.057 & 54.68 & 67.11 & 0.00 & 100.00 & 37.50 & 62.50 & 75.00 \\
\hline $\begin{array}{l}\text { The way they communicate } \\
\text { with people they know well }\end{array}$ & 70 & 85.00 & 17.368 & 80.86 & 89.14 & 25.00 & 100.00 & 75.00 & 87.50 & 100.00 \\
\hline $\begin{array}{l}\text { The way they communicate } \\
\text { with people they don't } \\
\text { know well }\end{array}$ & 70 & 62.86 & 23.407 & 57.28 & 68.44 & 0.00 & 100.00 & 50.00 & 75.00 & 75.00 \\
\hline $\begin{array}{l}\text { The way other people } \\
\text { communicate with them }\end{array}$ & 70 & 67.86 & 22.277 & 62.55 & 73.17 & 0.00 & 100.00 & 50.00 & 75.00 & 87.50 \\
\hline How they sleep & 70 & 73.21 & 19.883 & 68.47 & 77.96 & 25.00 & 100.00 & 75.00 & 75.00 & 87.50 \\
\hline $\begin{array}{l}\text { Their ability to keep up aca- } \\
\text { demically with their peers }\end{array}$ & 70 & 61.79 & 22.207 & 56.49 & 67.08 & 0.00 & 100.00 & 50.00 & 50.00 & 75.00 \\
\hline Their opportunities in life & 70 & 56.07 & 23.481 & 50.47 & 61.67 & 0.00 & 100.00 & 50.00 & 50.00 & 75.00 \\
\hline $\begin{array}{l}\text { The way they use their } \\
\text { arms }\end{array}$ & 70 & 58.21 & 25.080 & 52.23 & 64.19 & 0.00 & 100.00 & 50.00 & 50.00 & 75.00 \\
\hline $\begin{array}{l}\text { The way they use their } \\
\text { hands }\end{array}$ & 70 & 57.86 & 26.252 & 51.60 & 64.12 & 0.00 & 100.00 & 37.50 & 62.50 & 75.00 \\
\hline $\begin{array}{l}\text { Their ability to dress } \\
\text { themselves }\end{array}$ & 70 & 48.75 & 28.003 & 42.07 & 55.43 & 0.00 & 100.00 & 25.00 & 50.00 & 75.00 \\
\hline $\begin{array}{l}\text { Their ability to drink } \\
\text { independently }\end{array}$ & 70 & 60.71 & 33.398 & 52.75 & 68.68 & 0.00 & 100.00 & 25.00 & 75.00 & 87.50 \\
\hline
\end{tabular}


TABLE 1. Cont

\begin{tabular}{|c|c|c|c|c|c|c|c|c|c|c|}
\hline Group & $n$ & Average & SD & $-\mathrm{Cl} 95 \%$ & $+\mathrm{Cl} 95 \%$ & Min & $\operatorname{Max}$ & Q25 & Median & Q75 \\
\hline $\begin{array}{l}\text { Their ability to use the } \\
\text { toilet by themselves }\end{array}$ & 70 & 55.00 & 33.202 & 47.08 & 62.92 & 0.00 & 100.00 & 25.00 & 56.25 & 75.00 \\
\hline \multicolumn{11}{|c|}{ Participation and physical health } \\
\hline $\begin{array}{l}\text { Their ability to play with } \\
\text { friends }\end{array}$ & 70 & 76.25 & 19.753 & 71.54 & 80.96 & 25.00 & 100.00 & 62.50 & 75.00 & 87.50 \\
\hline $\begin{array}{l}\text { Being able to do things } \\
\text { they want to do }\end{array}$ & 70 & 63.75 & 27.678 & 57.15 & 70.35 & 0.00 & 100.00 & 50.00 & 75.00 & 87.50 \\
\hline $\begin{array}{l}\text { Their ability to participate } \\
\text { at preschool or school }\end{array}$ & 57 & 75.44 & 20.724 & 69.94 & 80.94 & 25.00 & 100.00 & 62.50 & 75.00 & 87.50 \\
\hline $\begin{array}{l}\text { Their ability to participate } \\
\text { in recreational activities }\end{array}$ & 70 & 71.07 & 22.776 & 65.64 & 76.50 & 25.00 & 100.00 & 50.00 & 75.00 & 87.50 \\
\hline $\begin{array}{l}\text { Their ability to participate } \\
\text { in sporting activities }\end{array}$ & 70 & 56.61 & 26.980 & 50.17 & 63.04 & 0.00 & 100.00 & 37.50 & 50.00 & 75.00 \\
\hline $\begin{array}{l}\text { Their ability to participate } \\
\text { in social events outside of } \\
\text { preschool or school }\end{array}$ & 70 & 68.57 & 22.994 & 63.09 & 74.05 & 12.50 & 100.00 & 50.00 & 75.00 & 87.50 \\
\hline $\begin{array}{l}\text { Their ability to participate } \\
\text { in their community }\end{array}$ & 70 & 70.89 & 18.882 & 66.39 & 75.40 & 25.00 & 100.00 & 50.00 & 75.00 & 87.50 \\
\hline Their physical health & 70 & 46.61 & 24.811 & 40.69 & 52.52 & 0.00 & 100.00 & 25.00 & 50.00 & 75.00 \\
\hline The way they get around & 70 & 39.29 & 25.026 & 33.32 & 45.25 & 0.00 & 100.00 & 25.00 & 37.50 & 50.00 \\
\hline $\begin{array}{l}\text { Their ability to keep up } \\
\text { physically with their peers }\end{array}$ & 70 & 43.75 & 24.795 & 37.84 & 49.66 & 0.00 & 100.00 & 25.00 & 50.00 & 50.00 \\
\hline The way they use their legs & 70 & 41.96 & 26.838 & 35.57 & 48.36 & 0.00 & 100.00 & 25.00 & 43.75 & 62.50 \\
\hline \multicolumn{11}{|c|}{ Emotional well-being and self-esteem } \\
\hline $\begin{array}{l}\text { The way they get along } \\
\text { with you }\end{array}$ & 70 & 91.43 & 11.567 & 88.67 & 94.19 & 50.00 & 100.00 & 87.50 & 100.00 & 100.00 \\
\hline The way they look & 70 & 73.57 & 18.374 & 69.19 & 77.95 & 37.50 & 100.00 & 50.00 & 75.00 & 87.50 \\
\hline Their life in general & 70 & 74.29 & 20.176 & 69.47 & 79.10 & 25.00 & 100.00 & 50.00 & 75.00 & 87.50 \\
\hline Themselves & 70 & 68.93 & 20.384 & 64.07 & 73.79 & 25.00 & 100.00 & 50.00 & 75.00 & 75.00 \\
\hline Their future & 70 & 59.46 & 21.852 & 54.25 & 64.67 & 0.00 & 100.00 & 50.00 & 50.00 & 75.00 \\
\hline How happy is your child? & 70 & 83.93 & 17.696 & 79.71 & 88.15 & 0.00 & 100.00 & 75.00 & 87.50 & 100.00 \\
\hline \multicolumn{11}{|l|}{ Access to services } \\
\hline $\begin{array}{l}\text { The special equipment they } \\
\text { have at home }\end{array}$ & 48 & 65.63 & 22.846 & 58.99 & 72.26 & 0.00 & 100.00 & 50.00 & 75.00 & 75.00 \\
\hline $\begin{array}{l}\text { The special equipment they } \\
\text { have at their school }\end{array}$ & 40 & 64.38 & 20.324 & 57.88 & 70.87 & 0.00 & 100.00 & 50.00 & 62.50 & 75.00 \\
\hline $\begin{array}{l}\text { The special equipment } \\
\text { that is available in the } \\
\text { community }\end{array}$ & 48 & 55.99 & 22.180 & 49.55 & 62.43 & 0.00 & 100.00 & 50.00 & 50.00 & 75.00 \\
\hline $\begin{array}{l}\text { Your child's access } \\
\text { to treatment }\end{array}$ & 70 & 46.25 & 24.575 & 40.39 & 52.11 & 0.00 & 87.50 & 25.00 & 37.50 & 75.00 \\
\hline $\begin{array}{l}\text { Your child's access } \\
\text { to therapy }\end{array}$ & 70 & 46.07 & 26.796 & 39.68 & 52.46 & 0.00 & 100.00 & 25.00 & 37.50 & 75.00 \\
\hline $\begin{array}{l}\text { Your child's access } \\
\text { to specialised medical } \\
\text { or surgical care }\end{array}$ & 70 & 51.07 & 24.886 & 45.14 & 57.01 & 0.00 & 100.00 & 37.50 & 50.00 & 75.00 \\
\hline $\begin{array}{l}\text { Your ability to get advice } \\
\text { from a paediatrician }\end{array}$ & 70 & 68.57 & 22.496 & 63.21 & 73.94 & 0.00 & 100.00 & 62.50 & 75.00 & 75.00 \\
\hline $\begin{array}{l}\text { Your child's access to } \\
\text { community services and } \\
\text { facilities }\end{array}$ & 70 & 57.32 & 25.933 & 51.14 & 63.50 & 0.00 & 100.00 & 37.50 & 62.50 & 75.00 \\
\hline
\end{tabular}


TABLE 1. Cont.

\begin{tabular}{|c|c|c|c|c|c|c|c|c|c|c|}
\hline Group & $n$ & Average & SD & $-\mathrm{Cl} 95 \%$ & $+\mathrm{Cl} 95 \%$ & Min & Max & Q25 & Median & Q75 \\
\hline $\begin{array}{l}\text { Your child's access to extra } \\
\text { help with learning at } \\
\text { preschool or school }\end{array}$ & 70 & 53.39 & 25.795 & 47.24 & 59.54 & 0.00 & 100.00 & 37.50 & 50.00 & 75.00 \\
\hline \multicolumn{11}{|l|}{ Pain and impact of disability } \\
\hline $\begin{array}{l}\text { Is your child bothered by } \\
\text { hospital visits? }\end{array}$ & 70 & 45.54 & 35.549 & 37.06 & 54.01 & 0.00 & 100.00 & 12.50 & 50.00 & 75.00 \\
\hline $\begin{array}{l}\text { Is your child bothered } \\
\text { when they miss school for } \\
\text { health reasons? }\end{array}$ & 70 & 69.11 & 33.630 & 61.09 & 77.13 & 0.00 & 100.00 & 50.00 & 75.00 & 100.00 \\
\hline $\begin{array}{l}\text { Is your child bothered by } \\
\text { being handled by other } \\
\text { people? }\end{array}$ & 70 & 63.21 & 31.700 & 55.66 & 70.77 & 0.00 & 100.00 & 50.00 & 62.50 & 100.00 \\
\hline $\begin{array}{l}\text { Does your child worry } \\
\text { about who will take care } \\
\text { of them in the future? }\end{array}$ & 70 & 85.00 & 24.227 & 79.22 & 90.78 & 0.00 & 100.00 & 75.00 & 100.00 & 100.00 \\
\hline $\begin{array}{l}\text { Is your child concerned } \\
\text { about having cerebral palsy? }\end{array}$ & 70 & 72.32 & 34.962 & 63.99 & 80.66 & 0.00 & 100.00 & 50.00 & 87.50 & 100.00 \\
\hline $\begin{array}{l}\text { How much pain does your } \\
\text { child have? }\end{array}$ & 70 & 54.64 & 31.863 & 47.05 & 62.24 & 0.00 & 100.00 & 25.00 & 62.50 & 75.00 \\
\hline $\begin{array}{l}\text { How does your child feel } \\
\text { about the amount of pain } \\
\text { they have? }\end{array}$ & 70 & 74.64 & 30.094 & 67.47 & 81.82 & 0.00 & 100.00 & 50.00 & 87.50 & 100.00 \\
\hline $\begin{array}{l}\text { How much discomfort does } \\
\text { your child experience? }\end{array}$ & 70 & 46.43 & 31.647 & 38.88 & 53.97 & 0.00 & 100.00 & 25.00 & 50.00 & 75.00 \\
\hline \multicolumn{11}{|l|}{ Family health } \\
\hline Your physical health & 70 & 62.32 & 24.680 & 56.44 & 68.21 & 0.00 & 100.00 & 50.00 & 75.00 & 75.00 \\
\hline Your work situation & 70 & 50.18 & 26.020 & 43.97 & 56.38 & 0.00 & 100.00 & 25.00 & 50.00 & 75.00 \\
\hline $\begin{array}{l}\text { Your family's financial } \\
\text { situation }\end{array}$ & 70 & 56.96 & 23.854 & 51.28 & 62.65 & 0.00 & 87.50 & 37.50 & 62.50 & 75.00 \\
\hline How happy are you? & 70 & 72.68 & 21.733 & 67.50 & 77.86 & 0.00 & 100.00 & 62.50 & 75.00 & 87.50 \\
\hline
\end{tabular}

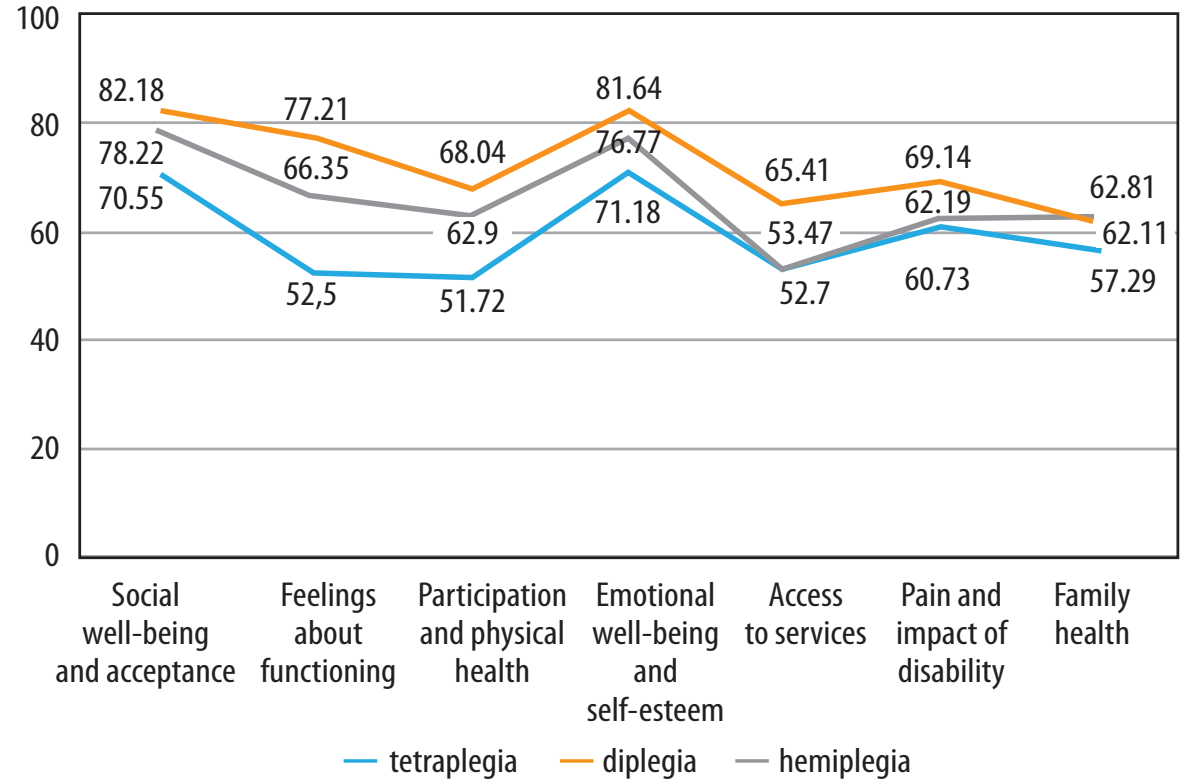

FIGURE 3. Distribution of medium areas of CP QOL-Child in groups of cerebral palsy 
affecting the quality of life of children with spastic cerebral palsy. In their study, they indicate that interventions to reduce pain and fatigue can improve school-related functioning in this group of children [16].

The author's own research using CP QOL-Child indicates that the lowest score of all domains was received by the access to health services as well as physical health and participation. According to the surveyed patients, their highest quality of life concerns the area of participation in social life, social acceptance, and emotional state. The results obtained are similar to those achieved by other researchers. A similar classification of individual domains was presented, among others, by Wang, Böiling, Dmitruk, and Soilemani [7, 17-19]. In China, the average result for individual domains, calculated on a 100-point scale, was as follows: participation in social life and social acceptance - 76.7; functioning - 64.4; physical health and participation - 66.6; emotional condition - 73.3; pain and disability effects -60.0 ; access to health services -63.3 ; and health of parents/guardians - 61.1 [17]. The results from the Polish population published in 2014 showed similar mean scores obtained in specific domains determining the quality of life of children with cerebral palsy. They were, respectively: participation in social life and social acceptance -77.53 ; functioning -64.91 ; physical health and participation - 63.53; emotional condition 70.69; pain and disability effects -54.28 ; access to health services - 60.81; and health of parents/guardians - 60.12 [7]. Results of a study on the Finnish population are as follows: participation in social life and social acceptance 81.9; functioning - 76.3; physical health and participation - 71.3; emotional condition - 78.2; and pain and disability effects -64.3 . Unfortunately, access to health services and the health of parents/guardians were not assessed in this study [18]. The results obtained in the Persian version are as follows: participation in social life and social acceptance - 74.14; functioning - 63.30; physical health and participation - 66.25; emotional condition - 70.50; pain and disability effects - 56.48; access to health services 56.06; and the health of parents/guardians - 48.61 [19]. Data on the population of patients in Turkey gathered by Usyal et al. differ slightly from those presented above. The highest rated areas were participation in social life and acceptance (73.65) and the emotional domain (73.21) followed by the health of parents/guardians (68.85), functioning (68.34), physical health and participation (65.86), and access to benefits (48.36). The lowest score was obtained for pain and disability effects (39.80) [20].

When planning our own study on the quality of life of patients with cerebral palsy, it was assumed that the assessment would be performed both by the patients and their parents. Unfortunately, mental disability and communication difficulties in most people forced the surveyors to modify the study and limit the analysis to the assessment made only by the carers of patients with cerebral palsy.
People with disabilities are equally entitled to maintain their dignity and independence and to fully participate in society. Allowing them to exercise this right is at the centre of the European Union (EU) actions and the UN Convention on the Rights of Persons with Disabilities. The aim of the Convention is to promote, protect, and ensure the full and equal enjoyment of all human rights and fundamental freedoms for people with disabilities. The provisions of the convention are a significant step forward: disability is presented not only as a social welfare problem but also as a legal issue related to human rights. The convention reflects the basic elements of the EU Strategy on Disability for the years 2010-2020, which pertains both to actions against discrimination, the policy of equal opportunities, and active integration into society. The rights adopted in the convention cover almost all policy areas, while the EU disability strategy aims to ensure full implementation of these rights [5].

\section{CONCLUSIONS}

The results obtained have shown a significant deficit in the quality of life of children and adolescents with cerebral palsy in terms of problems arising from the disease entity. The following domains received the lowest score: daily routines, mobility and keeping balance, activities performed at school, as well as access to health services, physical health, and participation.

The therapy should be focused on appropriate adjustment of the home and school environment to the patient's needs, as well as developing such skills that enable selfcare or assisting in everyday self-care and school activities. It seems appropriate to conduct targeted educational activities of a team of specialists working with children to provide parents with knowledge about the nature of their child's disease and its impact on the functioning of the family.

\section{DISCLOSURE}

The authors declare no conflict of interest.

\section{REFERENCES}

1. Rosenbaum P, Paneth N, Leviton A, et al. A report: The definition and classification of cerebral palsy April 2006. Dev Med Child Neurol Suppl 2007; 109: 8-14.

2. Colver A, Fairhurst C, Pharoah PO. Cerebral palsy. Lancet 2014; 383: 1240-1249.

3. Butler C, Darrah J. Effects of neurodevelopmental treatment (NDT) for cerebral palsy: an AACPDM evidence report. Dev Med Child Neurol 2001; 43: 778-790.

4. Michalska A, Markowska M, Śliwiński Z, et al. Quality of life in children and young people with tetraplegic cerebral palsy. Med Stud 2018; 34: 112-119.

5. Publications Office of the European Union. European Commission's program "European Disability for 2010-2020: A Renewed Com- 
mitment to a Barrier-Free Europe" DOI: 10.2767/28357 (access: 15.12.2018).

6. Accardo P, Accardo J, Capute A. A neurodevelopmental perspective on the continuum of developmental disabilities. In: Capute \& Accardo's Neurodevelopmental Disabilities in Infancy and Childhood. $3^{\text {rd }}$ ed., Accardo P (ed.). MD: Brookes, Baltimore 2007; 3-26.

7. Dmitruk E, Mirska A, Kułak W, et al. Psychometric properties and validation of the Polish CP QOL-Child questionnaire: a pilot study. Scand J Caring Sci 2014; 28: 878-884.

8. Michalska A, Wendorff J, Boksa E, Wiktor PJ. Jakość życia dzieci i młodzieży z mózgowym porażeniem dziecięcym i niepełnosprawnością intelektualną. Wybrane uwarunkowania kliniczne. Neurol Dziec 2012; 21: 39-48.

9. Okurowska-Zawada B, Kułak W, Otapowicz D, et al. Quality of life in children and adolescents with cerebral palsy and myelomeningocele. Pediatr Neurol 2011; 45: 163-168.

10. Chmielik A. A survey of health related quality of life (HRQL) in children with cerebral palsy. New Medicine 2012, 4: 108-113.

11. Varni JW, Burwinkle TM, Berrin SJ, et al. The PedsQL in pediatric cerebral palsy: reliability, validity, and sensitivity of the Generic Core Scales and Cerebral Palsy Module. Dev Med Child Neurol 2006; 48: 442-449.

12. Yang X, Xiao N, Yan J. The PedsQL in pediatric cerebral palsy: reliability and validity of the Chinese version pediatric quality of life inventory 4.0 generic core scales and 3.0 cerebral palsy module. Qual Life Res 2011; 20: 243-252.

13. Houlihan CM, O'Donnell M, Conaway M, et al. Bodily pain and health-related quality of life in children with cerebral palsy. Dev Med Child Neurol 2004; 46: 305-310.

14. Hirsh AT, Gallegos JC, Gertz KJ, et al. Symptom burden in individuals with cerebral palsy. J Rehabil Res Dev 2010; 47: 863-876.

15. Arnaud C, White-Koning M, Michelsen SI, et al. Parent-reported quality of life of children with cerebral palsy in Europe. Pediatrics 2008; 121: 54-64.

16. Berrin SJ, Malcarne VL, Varni JW, et al. Pain, fatigue, and school functioning in children with cerebral palsy: a path-analytic model. J Pediatr Psychol 2007; 32: 330-337.

17. Wang H-Y, Cheng C-C, Hung J-W, et al. Validating the Cerebral Palsy Quality of Life for Children (CP QOL-Child) questionnaire for use in Chinese populations. Neuropsych Rehab 2010; 20: 883-898.

18. Böiling S, Tarjaa V, Helenab M, et al. Measuring quality of life of Finnish children with cerebral palsy. J Pediatr Rehabil Med 2013; 6: 121-127.

19. Soleimani F, Vameghi R, Kazemnejad A, et al. Psychometric Properties of the Persian Version of Cerebral Palsy Quality of Life Questionnaire for Children. Iran J Child Neurol 2015; 9: 76-86.

20. Uysal SA, Düger T, Elbasan B, et al. Reliability and Validity of The Cerebral Palsy Quality of Life Questionnaire in The Turkish Population. Percept Mot Skills 2016; 122: 150-164. 